Brazilian Journal of Political Economy, vol. 41, $n^{\circ}$ 3, pp. 525-537, July-September/2021

\title{
Legalization of drugs and strategic behaviour
}

\author{
Legalização das drogas e comportamento estratégico
}

VINÍCIUS PHILLIPE DE ALBUQUERQUEMELLO*;**

FRANCISCO S. RAMOS***

\begin{abstract}
RESUMO: O crescente número de usuários, cerca de 250 milhões, em 2016, e a enorme quantidade de problemas de saúde, que causam 190.000 mortes por ano, são alguns dos dados que reacenderam o debate a respeito da eficácia das políticas proibicionistas ao consumo de drogas, em todo o mundo. Daí, criando um ramo da literatura voltado à investigação dessa temática. Nesse sentido, o presente artigo analisa economicamente os cenários em que não há legalização das drogas e para legalizações parciais (maconha) ou integrais, à luz da Teoria dos Jogos. Assim, consegue, diferentemente de outros estudos, determinar condições de compatibilidade de incentivos para que a economia venha realmente a se formalizar após a descriminalização, evitando contrabandos sob fachada legal. Além disso, consegue apontar qual a situação (equilíbrio de Nash) que propicia o maior bem-estar para a sociedade.

PALAVRAS-CHAVE: Tráfico de drogas; contrabando; legalização; Teoria dos Jogos.
\end{abstract}

ABSTRACT: The growing number of users, about 250 million, in 2016, and the sheer number of health problems, that cause 190,000 deaths per year, are just some of the data that has rekindled the debate and discussion into the efficiency of the prohibitionist drug policies concerning drug consumption throughout the world. As a result, there has been the establishment of a special branch of literature focused on the investigation into this theme. In this regard, the present article conducts an economic analysis of scenarios where there is no decriminalization of drugs and other areas where legalization has been partial (marijuana) or complete, based on Game Theory. Thus, different from other studies, this paper establishes conditions of compatibility of incentives so that the economy could become formal, after decriminalization, to avoid contraband under a legal guise. This paper also manages to show which situation (Nash equilibrium) provides the greatest well-being for society. KEYWORDS: Drug trafficking; smuggling; drug legalization; Game Theory. JEL Classification: C70; D6; H26.

\footnotetext{
* Assistant professor of Economics and Finance at the Federal University of Paraíba, João Pessoa/PB, Brazil. Email: vinicius.phillipe@hotmail.com. Orcid: https://orcid.org/0000-0003-0487-7320.

* Ph.D. candidate in Economics at Federal University of Pernambuco, Recife/PE, Brasil

$* *$ Professor of Economics at Federal University of Pernambuco/LabGRC, Recife/PE, Brasil. E-mail: francisco.ramos@ufpe.br; Orcid: https://orcid.org/0000-0001-7087-9792. Submitted: 28/November/2019; Approved: 7/October/2020.
} 


\section{INTRODUCTION}

In recent years, doubts have been raised about the efficiency of prohibitionist policies as a way of dealing with drug consumption, considering the steadily increasing number of users. According to the World Drug Report (2017), published by the United Nations (UN), in the year 2016 more than 250 million people, or just over $5 \%$ of the world population aged between 15 and 64 , consumed some kind of illicit drug. The situation warrants even more serious concern when we consider the fact that $10 \%$ of these drug users have some kind of health problem caused by drug use. Also, some 190,000 people die every year throughout the world because of drug overdoses, most of these through the overuse of opioids. According to the National Centre for Health Studies - NCHS (2017), in 2016 some 63,600 people died from drug overdoses in the United States alone.

Looking at the costs caused to the public budget as a result of health treatment, rehabilitation of chemical addicts, crimes, and loss of productivity at work, all resulting from illicit substance abuse, the National Institute on Drug Abuse - NIDA (2019) says that the total cash value of losses generated comes to at least USD 193 billion, this being even more significant if we consider medically prescribed opioids which bring an additional loss of USD 78.5 billion.

This has kindled the debate about whether or not to decriminalize some drugs such as marijuana. In this case, several are the points that can be considered as being in favor of the decriminalization of such products, these being: i) receipt of additional tax income, with taxes levied on the consumption of these products; ii) setting up a database of drug users and, as a result, statistics about this segment of the population; iii) reduction of one of the possible sources of income for organized crime organizations; iv) creation of formal jobs; v) greater possibility of further studies for the development of medication; vi) end of the 'forbidden fruit' effect, which leads many young people to want to try it out just through the fact that there is some restriction on its use; vii) reduction in the prison population which, according to the Federal Bureau of Prisons - FOB (2019) has some $46 \%$ of the total prison population imprisoned due to drug-related crimes. ${ }^{1}$.

According to the Tax and Budget Bulletin (2018) of the Cato Institute, with the legalization of marijuana alone, in the United States, one could have a general budget gain of some USD 107 billion, of which USD 59 billion would be generated by taxes and the other USD 48 billion resulting from the cuts in costs incurred with the prohibition and repression of drug consumption.

However, the analysis of this legal change is not so trivial, as one must also bear in mind that: a) the use of drugs can cause chemical dependency, as also health problems and increased occurrence of accidents in the workplace; b) drug use affects salary remuneration (Ours, 2007; Popovici and French, 2014) as also produc-

\footnotetext{
${ }^{1}$ For further information about the profiles of the prison inmates for drug-related offences, see Appendix A.
} 
tivity at work (Zarkin et al., 1998); c) some studies show that the use of drugs helps to worsen students' academic performance (Dewey, 1999; Sutherland and Shepherd, 2001; Jeynes, 2002), as well as increasing student truancy (Arria et al., 2013); d) some research papers also show that the use of drugs by teenagers shows a positive correlation with increased rates of teenage pregnancy (Yamaguchi and Kandel, 1987; Rashad and Kaestner, 2004); e) the legalization of drugs may make them more widespread (Becker; Murphy; Grossman, 2006).

According to Becker, Murphy and Grossman (2006), prohibition is not the most effective policy for tackling the prevalence of the drug trade because, as it considers social and private costs associated with drug consumption and elasticity of supply and demand for these goods, one can see that criminalization and repression are only effective if supply and demand are elastic. This occurs because, if the demand and the supply are not elastic, greater enforcement by the Government to stamp out the drug trade will only make drug traffickers charge higher prices, to replace the additional costs, and accept greater risk of incarceration. Hence, as there is no reduction in demand, there is a greater social cost associated with narcotics.

Many empirical studies have shown that the supply and demand for some drugs are inelastic, considering drugs' capacity to cause chemical addiction among the users. Among these studies, we could mention Nisbet and Vakil (1972) who looked at the price-demand elasticity for the consumption of marijuana by students of the University of California at Los Angeles (UCLA); Ours (1995) who estimated pricedemand elasticity, in the short and the long term, regarding the consumption of opium immediately before the Second World War; Saffer and Chaloupka (1999) who calculated the price-demand elasticity for the use of heroin; Gallet (2014) who carried out a meticulous study of a range of drugs, using meta-analysis.

On the other hand, the legalization and the resulting introduction of ad valorem taxation on drug consumption, together with enforcement applied against the informal market, would mean that the drug traffickers would only want to work as formal workers. In this way, the Government can apply taxes on consumption using a progressive structure, which reduces the production, due to the reduction of the profit as expected by the manufacturers (Becker; Murphy; Grossman, 2006).

However, what kind of action should be taken? Maybe partial decriminalization, including only those drugs that are least bad for health, like marijuana? Or the legalization of all drugs? Wouldn't the first situation be the continuity of drug dealers as elements of the trafficking of heavier drugs, thereby creating a legal façade for this kind of crime? In this way, would the supply, and hence the consumption, tend to expand, reducing social well-being? Also, considering the options for the decriminalization of this market, which situation would provide the level of tax income, which is necessary for maximizing the well-being of society at large?

For this purpose, this paper proposes a theoretical analysis through Game Theory, creating a model of the drugs market, in which traffickers must make their decision about whether or not to stay in legal operation, considering the scenarios in which the State does not legalize, partially legalizes, or fully legalizes this commerce. 
According to Gibbons (1997) and Neumann and Morgenstern (2007), Game Theory is a branch of Mathematics that seeks to study interactions among rational economic players, which could lead to cooperation or conflict and solve situations of uncertainty. This type of approach is very relevant, as it allows one to establish a situation of equilibrium, which is efficient and Pareto superior. Also, it provides the possibility to analyze well-being, by the exercising of comparative statics with money metrics, about public funding.

The rest of the article is organized as follows. In the second section, we present the methodology and development of the work project, considering the theoretical model of the game thus developed. Third section looks at the equilibrium of the game, and also carries out an analysis of well-being. In the fourth section, we see an application and an empirical strategy. Fifth section brings the results, and then the final section presents the closing comments on the study.

\section{THE THEORETICAL MODEL}

The development of this work starts from the preparation of a sequential game involving two participants, namely the State and the Drug Dealers. The first player may decide to only decriminalize marijuana (LP), to decriminalize drug use in general (LT), or keep drugs illicit (NL). If the player decides in favour of partial decriminalization, then only a proportion $\gamma \in(0,1)$ of the income received through the illegal sale of drugs shall indeed be taxed. The drug dealer shall have to choose whether the drug dealer shall act legitimately $(\mathrm{VL})$, smuggle $(\mathrm{C})$ or, in the case of the partial decriminalization of narcotics, remain as a dealer of illicit drugs (T). As a result of the acts of the drug dealer, there is then a possibility $p \in(0,1)$ of whether he/she will be arrested or not, this value is assigned at random by nature. Based on the strategies adopted by each player, there is a payoff for each of the existing 10 scenarios. The result of the State is shown by the value function $\mathrm{V}($.$) ,$ and the gains made by the drug dealer are shown by the function $\mathrm{U}($.$) . The format$ of this game is shown in Figure 1 below.

The payoffs for each scenario, for each player, are shown in greater detail in Table 1, which follows hereunder, where $\tau$ is the tax levied upon the income obtained through the sale of legalized drugs, $\mathrm{R}_{\mathrm{L}}, \mathrm{C}_{\mathrm{s}, \mathrm{l}, \mathrm{p}, \mathrm{j}}\left(\mathrm{R}_{\mathrm{IL}}\right)$ are the Government costs with health, law enforcement, policing, and Court costs, all of which depend on the volume of illicit drugs being sold to the society considered. One point worthy of mention is that, for the contexts in which there is a simulation of legalization of drugs, the costs for the Government shall be reduced to $\mathrm{C}_{\mathrm{p}}(\mathrm{RL})$, as the health expenses of drug users are internalized, and there are no more expenses with law enforcement and judicialization of cases. $\mathrm{R}_{\mathrm{IL}}$ is the income obtained with the sale of illicit drugs. We can see that, in some cases, when the drug dealer is arrested, the income generated by the illicit drugs appears in the State payoff, as it is a result of confiscation. $\mathrm{C}_{\text {trafic }}$ is the cost of the opportunity that the drug dealers have, on entering the underworld of crime (the average salary paid to the modal profile of drug dealers, 
Figure 1: Sequential game of perfect information

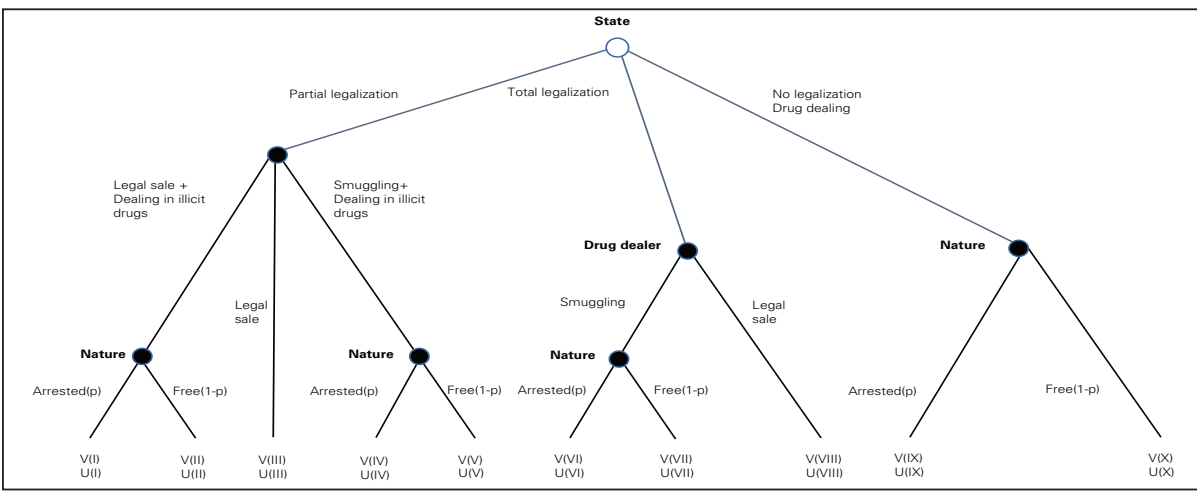

Source: Prepared by the authors.

calculated based on the average term of imprisonment as stated in Court sentences). $\mathrm{C}_{\text {contrab }}$ is similar to the cost of the previous opportunity, in the case where the drug dealer deals with the black market. $\mathrm{C}_{\mathrm{adv}}$ is the cost incurred by the drug dealer for the payment of legal fees, when under arrest. $\mathrm{C}_{\text {arm }}\left(\mathrm{R}_{\mathrm{IL}}\right)$ is the cost that the drug dealer shall have when buying weaponry to maintain the trap house.

Table 1: Payoffs for players, for each scenario

\begin{tabular}{|c|c|c|}
\hline Scenario & State & Drug Dealer \\
\hline I & $\tau R_{L}+R_{\| L}-C_{s, l, p, j}\left(R_{L L}\right)$ & $(1-\tau) R_{L}-C_{\text {trafic }}-C_{\text {arm }}\left(R_{I L}\right)-C_{a d v}$ \\
\hline II & $\tau R_{L}-C_{s, l, p, j}\left(R_{l L}\right)$ & $\begin{array}{l}(1-\tau) R_{L}+R_{I L}-C_{\text {trafic }}-C_{\text {arm }}\left(R_{L L}\right) \\
-C_{a d v}\end{array}$ \\
\hline III & $\tau R_{L}-C_{s, l, p, j}\left(R_{L L}\right)$ & $(1-\tau) R_{L}$ \\
\hline IV & $R_{L L}-C_{s, l, p, j}\left(R_{L L}\right)$ & - $C_{\text {contrab }}-C_{a r m}\left(R_{I L}\right)-C_{a d v}$ \\
\hline V & $-C_{s, l, p, j}\left(R_{I L}\right)$ & $R_{I L}-C_{\text {trafic }}-C_{\text {contrab }}-C_{\text {arm }}\left(R_{L L}\right)$ \\
\hline VI & $R_{/ L}-C_{p}\left(R_{L}\right)$ & - $C_{\text {contrab }}-C_{a r m}\left(R_{I L}\right)-C_{a d v}$ \\
\hline VII & $-C_{p}\left(R_{L}\right)$ & $R_{I L}-C_{\text {contrab }}-C_{a r m}\left(R_{I L}\right)$ \\
\hline VIII & $\tau R_{L}-C_{p}\left(R_{L}\right)$ & $(1-\tau) R_{L}$ \\
\hline IX & $R_{\| L}-C_{s, l, p, j}\left(R_{L L}\right)$ & $-C_{\text {trafic }}-C_{\text {arm }}\left(R_{L L}\right)-C_{a d v}$ \\
\hline$x$ & - $C_{s, l, p, j}\left(R_{L}\right)$ & $R_{I L}-C_{\text {trafic }}-C_{\text {arm }}\left(R_{L L}\right)$ \\
\hline
\end{tabular}

Source: Prepared by the authors.

Before we look into the equilibrium of the game, we note that, among the payoffs shown in Table 1, we know that, when the drug dealer is not arrested, then he or she has higher gains, as the sum received by trading in drugs, whether by trafficking or smuggling, is not confiscated by the Government. Also, if the drug dealer is then discovered, apart from the penalty (which is based on the cash value 
of the drugs), there shall also be legal fees. This means that $\mathrm{U}(\mathrm{II})>\mathrm{U}(\mathrm{I}) ; \mathrm{U}(\mathrm{V})>$ $\mathrm{U}(\mathrm{IV}) ; \mathrm{U}(\mathrm{VII})>\mathrm{U}(\mathrm{VI})$ and $\mathrm{U}(\mathrm{X})>\mathrm{U}(\mathrm{IX})$. On the other hand, the State ensures greater return whenever, at the end of the possibilities of action, they manage to arrest the drug dealer.

Also, if we compare the payoffs of the drug negotiations for situations VI and IX, we see that $\mathrm{U}(\mathrm{VI})$ shall be less than $\mathrm{U}(\mathrm{IX})$ only if the cost of opportunity (punishment) for the contraband was less than the sanctions applied against drug trafficking.

Finally, on comparing the rates of return for scenarios X and VIII, knowing that in the first case the income obtained legally through the sale of drugs shall be taxed, and that in the second case there shall be costs for the drug dealer, as he or she shall be working with an illicit product. Also, the volume of such costs has an absolute value is less than the loss of income with the payment of taxes. This means that $\mathrm{U}(\mathrm{X})$ shall be less than, or equal to, $\mathrm{U}(\mathrm{VIII})$, ceterus paribus. This fact shall only not be confirmed if the legalization of this market leads to a strong increase in supply and demand for narcotics, which, as a result, expands income and compensates for the losses incurred through reduction of prices $^{2}$ and tax compliance.

This means that we can detect a relationship of order among the payoffs, for each agent. For drug dealers, ordering the value function from the worst to the best results, we get the following results:

$$
\begin{aligned}
& \mathrm{U}(\mathrm{VI}) \leq \mathrm{U}(\mathrm{IX})<\mathrm{U}(\mathrm{IV})<\mathrm{U}(\mathrm{I})<\mathrm{U}(\mathrm{III})<\mathrm{U}(\mathrm{II})<\mathrm{U}(\mathrm{V})<\mathrm{U}(\mathrm{VII}) \leq \mathrm{U}(\mathrm{X}) \leq \mathrm{U}(\mathrm{VIII}) . \\
& \mathrm{Or} \\
& \mathrm{U}(\mathrm{VI}) \leq \mathrm{U}(\mathrm{IX})<\mathrm{U}(\mathrm{IV})<\mathrm{U}(\mathrm{I})<\mathrm{U}(\mathrm{III})<\mathrm{U}(\mathrm{II})<\mathrm{U}(\mathrm{V})<\mathrm{U}(\mathrm{VII}) \leq \mathrm{U}(\mathrm{VIII}) \leq \mathrm{U}(\mathrm{X}) . \\
& \mathrm{Or} \\
& \mathrm{U}(\mathrm{IX}) \leq \mathrm{U}(\mathrm{VI})<\mathrm{U}(\mathrm{IV})<\mathrm{U}(\mathrm{I})<\mathrm{U}(\mathrm{III})<\mathrm{U}(\mathrm{II})<\mathrm{U}(\mathrm{V})<\mathrm{U}(\mathrm{VII}) \leq \mathrm{U}(\mathrm{X}) \leq \mathrm{U}(\mathrm{VIII}) . \\
& \mathrm{Or} \\
& \mathrm{U}(\mathrm{IX}) \leq \mathrm{U}(\mathrm{VI})<\mathrm{U}(\mathrm{IV})<\mathrm{U}(\mathrm{I})<\mathrm{U}(\mathrm{III})<\mathrm{U}(\mathrm{II})<\mathrm{U}(\mathrm{V})<\mathrm{U}(\mathrm{VII}) \leq \mathrm{U}(\mathrm{VIII}) \leq \mathrm{U}(\mathrm{X}) .
\end{aligned}
$$

About the ordering of Government payoffs, we well know that this shall depend on whether the consumption of drugs and the price thereof shall vary at all after legalization, so that the income obtained from the commercialization of narcotics $\left(\mathrm{R}_{\mathrm{IL}}\right)$ shall expand or be reduced, becoming higher (or lower) than $\mathrm{R}_{\mathrm{L}}$ minus what is due in taxes. Also, this shall also depend on the social costs that the Government has to bear. This means that the following cases are possible:

\footnotetext{
${ }^{2}$ According to MacCoun and Reuter (1997), the price of decriminalized marijuana is some $50 \%$ of its value on the black market. According to Miron (2003), for cocaine the price of the illegal product is between 2 and 4 times the price if it was legalized. For heroin the difference is between 6 and 19 times.
} 


$$
\mathrm{V}(\mathrm{X})<\mathrm{V}(\mathrm{V})<\mathrm{V}(\mathrm{VII})<\mathrm{V}(\mathrm{II})<\mathrm{V}(\mathrm{III})<\mathrm{V}(\mathrm{IV})<\mathrm{V}(\mathrm{IX})<\mathrm{V}(\mathrm{I})<\mathrm{V}(\mathrm{VIII})<\mathrm{V}(\mathrm{VI}),
$$

for $\left(\mathrm{R}_{\mathrm{IL}}>\tau_{\mathrm{RL}}\right)$

Or

$\mathrm{V}(\mathrm{V})<\mathrm{V}(\mathrm{X})<\mathrm{V}(\mathrm{VII})<\mathrm{V}(\mathrm{IX})<\mathrm{V}(\mathrm{IV})<\mathrm{V}(\mathrm{III})<\mathrm{V}(\mathrm{II})<\mathrm{V}(\mathrm{VI})<\mathrm{V}(\mathrm{I})<\mathrm{V}(\mathrm{VIII})$, for $\left(\mathrm{R}_{\mathrm{IL}}<\tau_{\mathrm{RL}}\right)$

This means that the situations most beneficial to the Government are those where the Government avoids most of the social costs resulting from drug dealing, meaning that the only costs remaining shall be the indirect costs arising from drugrelated crimes. Also, the Government can garner tax revenue and confiscate the income obtained from selling drugs on the black market.

\section{EQUILIBRIUM OF THE GAME}

As seen before, the order of the payoffs of each agent shall depend on many factors: on the cash penalty to be applied against the drug dealer, for crimes of smuggling or drug trafficking; on the social cost that the State shall have about the volume of drugs consumed, whether legally or not; and also on how strong the variations in income from sales of narcotics shall be, in a simulation based on decriminalization.

Knowing that there is indeed a probability $\mathrm{p} \in(0,1)$ that the criminal shall be arrested, then we can establish the expected value of each action carried out by this player, about the strategy used by the Government, as shown in the payoff matrix in Table 2. The profile of strategies that was the best response for all the elements in the sequence of strategies taken up by the Government (providing the best results) and vice-versa establish the Nash equilibrium for this game.

Table 2: Matrix showing expected payoffs.

\begin{tabular}{|c|c|c|c|c|c|c|}
\hline & \multicolumn{5}{|c|}{ Drug Dealer } \\
\hline & & Trafficking & Smuggling & $\begin{array}{c}\text { Legal sales + } \\
\text { Trafficking }\end{array}$ & $\begin{array}{c}\text { Smuggling + } \\
\text { Trafficking }\end{array}$ & $\begin{array}{l}\text { Legal } \\
\text { Sales }\end{array}$ \\
\hline \multirow{3}{*}{ 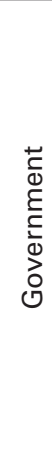 } & $\begin{array}{l}\text { Partially } \\
\text { legalized }\end{array}$ & - & - & $\begin{array}{c}p V(I)+ \\
(1-p) V(I I) \\
p U(I)+ \\
(1-p) \cup(I I)\end{array}$ & $\begin{array}{c}\mathrm{pV}(\mathrm{IV})+ \\
(1-\mathrm{p}) \mathrm{V}(\mathrm{V}) \\
\mathrm{pU}(\mathrm{IV})+ \\
(1-p) \cup(\mathrm{V})\end{array}$ & $V(I I I), U(I I I)$ \\
\hline & $\begin{array}{c}\text { Fully } \\
\text { legalized }\end{array}$ & - & $\begin{array}{c}p V(V I)+ \\
(1-p) V(V I I) \\
p U(V I)+ \\
(1-p) \cup(V I I)\end{array}$ & - & - & $\begin{array}{l}\text { V(VIII), } \\
\text { U(VIII) }\end{array}$ \\
\hline & $\begin{array}{c}\text { Not } \\
\text { legalized }\end{array}$ & $\begin{array}{c}\mathrm{p} V(I X)+ \\
(1-p) \bigvee(X) \\
p U(I X)+ \\
(1-p) \cup(X)\end{array}$ & - & - & - & - \\
\hline
\end{tabular}

Source: Prepared by the authors. 


\section{Equilibrium of the Game: Income from legal drugs higher than that of illicit drugs}

We are aware that the income obtained from drug sales after legalization may either grow or diminish when compared to that of illicit narcotics, due to the changes in demand and in the prices of the products. This means that we have some Nash equilibriums, respectively for each scenario.

First of all, we consider the case where RL $<$ RIL, or, in other words, where there is a reduction in income from drug sales, after legalization. If there is partial legalization of the commercialization and use of drugs, then the pair of strategies \{Partial legalization, Legal Sales\} shall be the Nash equilibrium if and only if the following holds:

$$
(1-\mathrm{p}) \mathrm{R}_{\mathrm{IL}}>\mathrm{C}_{\text {trafic }}-\mathrm{C}_{\text {arm }}\left(\mathrm{R}_{\mathrm{IL}}\right)+\mathrm{C}_{\text {adv }}
$$

In other words, if the income obtained with the sale of other illicit drugs does not exceed the costs incurred with the illegal operation. If this condition is not met, what shall in fact decide whether the Nash equilibrium shall move to pairs of strategies \{Partial legalization, Legal Sales + Trafficking other illicit drugs $\}$ or $\{$ Partial legalization, Smuggling + Trafficking $\}$ is the ratio between the cost of smuggling and the sum paid in taxes. If

$$
\mathrm{C}_{\text {contrab }}>\tau \gamma \mathrm{R}_{\mathrm{IL}}
$$

holds, then it shall be worth it for the trafficker to trade the drugs on the black market.

For a situation where there is total decriminalization of the commercialization and use of drugs, then the condition for the Nash equilibrium to be the pair of strategies $\{\mathrm{LT}, \mathrm{C}\}$ is given by the following equation:

$$
\mathrm{R}_{\mathrm{IL}}>\left(\mathrm{C}_{\text {contrab }}+\mathrm{C}_{\mathrm{arm}}(\mathrm{RIL})+\mathrm{pC}_{\mathrm{adv}}\right) /(1-\mathrm{p}-\gamma-\tau \gamma)
$$

In other words, the drug trafficker shall plan to operate illegally (smuggling) whenever the excess produced by the black market is more than its respective opportunity costs, considering the cash penalty enforced, cost of weaponry, lawyer's fees, and also the sum that shall be paid in taxes were the drug dealer to work legitimately. Otherwise, he or she shall seek to legalize. Therefore, the Nash equilibrium is $\{\mathrm{NT}, \mathrm{VL}\}$.

If there is no legalization, then the current situation shall be maintained, meaning that the Nash equilibrium would be to play $\{\mathrm{NL}, \mathrm{T}\}$.

\section{Equilibrium of the Game: Income from illicit drugs is higher than that of legalized drugs}

For the case where RL > RIL, the Nash equilibrium that contains the strategy that shall bring the highest expected payoff for the drug dealer for the scenario of legalization of use and commercialization of marijuana will be \{Partial Legislation, Legal Sale + Trafficking if and only if the criterion of Equation 1 is again followed. 
Otherwise, it would be more of an advantage to work exclusively in a legalized manner, with the Nash equilibrium then being the pair of strategies \{Partial legalization, Legal Sales\}.

If the Government decides to fully legalize consumption and commercialization of drugs, for the case where RL > RIL, then we have the Nash equilibrium containing the preferred strategy of the drug trafficker as being \{Full legalization, Legal Sales\} if and only if the relation shown below holds:

$$
\tau \mathrm{RL}>(1-\mathrm{p}) \Delta \mathrm{RL}-\mathrm{pRL} \text { - Ccontrab - Carm - pCadv }
$$

Last but not least, analyzing the scenario in which the Government keeps the laws as they stand and there is no legalization of drugs, then we have only one Nash equilibrium, which consists of the pair of strategies \{No legalization; Trafficking\}.

\section{Analysis of Well-Being and Superior Pareto Equilibrium}

The maximum excedent (well-being) that the Government could obtain shall consist of the establishment of the optimum point of the respective payoff function, as follows:

$$
\mathrm{W}_{\mathrm{Q}}=\mathrm{V}[\text { Tax income }(\mathrm{Q})]-\mathrm{V}[\text { Social costs }(\mathrm{Q})]
$$

In this equation, $\mathrm{W}$ represents government well-being. The tax income shall depend on the percentage tax charged (represented by the letter 'tau', $\tau$ ), which is a constant. Also, it shall also depend on the price of the drug, which is assumed as being given, assuming perfect competition in the sale of drugs and also in the quantity of drugs that are put on sale, Q. This last variable is established endogenously. Turning now to social costs, we see that these depend on how much is spent on health, education, law enforcement, policing, and judicialisation of cases, which shall also grow according to the level of $\mathrm{Q}$. Also, we assume that $\partial \mathrm{R}(\mathrm{Q}) / \partial \mathrm{Q}>0, \partial \mathrm{C}(\mathrm{Q}) / \partial \mathrm{Q}>$ $\left.0, \partial^{2} \mathrm{R}(\mathrm{Q})\right) / \partial \mathrm{Q}^{2}>0, \partial^{2} \mathrm{C}(\mathrm{Q}) / \partial \mathrm{Q}^{2}>0, \mathrm{~W} 0=0$. This means we can derive the conditions of the first order (CFO) for Government payoffs, as shown in Table 3.

Table 3: Nash Equilibriums and Excedent Generated by the Government

\begin{tabular}{|c|c|}
\hline Nash Equilibrium & Government Payoff \\
\hline$\{\mathrm{LP}, \mathrm{VL}\}$ & $\tau \mathrm{R}_{\mathrm{L}}-\mathrm{C}_{\mathrm{s}, \mathrm{l}, \mathrm{p}, \mathrm{j}}\left(\mathrm{R}_{\mathrm{IL}}\right)$ \\
\hline$\{\mathrm{LP}, \mathrm{VL}+\mathrm{T}\}$ & $\tau \mathrm{R}_{\mathrm{L}}+\mathrm{pR}_{\mathrm{IL}}-\mathrm{C}_{\mathrm{s}, \mathrm{l}, \mathrm{p}, \mathrm{j}}\left(\mathrm{R}_{\mathrm{IL}}\right)$ \\
\hline$\{\mathrm{LP}, \mathrm{C}+\mathrm{T}\}$ & $\mathrm{pR}_{\mathrm{IL}}-\mathrm{C}_{\mathrm{s}, \mathrm{l}, \mathrm{p}, \mathrm{j}}\left(\mathrm{R}_{\mathrm{IL}}\right)$ \\
\hline$\{\mathrm{LT}, \mathrm{C}\}$ & $\mathrm{pR}_{\mathrm{IL}}-\mathrm{C}_{\mathrm{p}}\left(\mathrm{R}_{\mathrm{L}}\right)$ \\
\hline$\{\mathrm{LT}, \mathrm{VL}\}$ & $\tau \mathrm{R}_{\mathrm{L}}-\mathrm{C}_{\mathrm{p}}\left(\mathrm{R}_{\mathrm{L}}\right)$ \\
\hline$\{\mathrm{NL}, \mathrm{T}\}$ & $\mathrm{pR}_{\mathrm{IL}}-\mathrm{C}_{\mathrm{s}, \mathrm{l}, \mathrm{p}, \mathrm{j}}\left(\mathrm{R}_{\mathrm{IL}}\right)$ \\
\hline
\end{tabular}

Source: Prepared by the authors.

Therefore, we have that the optimum well-being that the Government can assure in each Nash equilibrium is: 


$$
\begin{array}{lc}
\tau R_{L}^{\prime}=C_{s, l, p, j}^{\prime}\left(R_{I L}\right) & {[6]} \\
\tau R_{L}^{\prime}+p R^{\prime}=C_{s, l, p, j}^{\prime}\left(R_{I L}\right) & {[7]} \\
p R_{I L}^{\prime}=C_{s, l, p, j}^{\prime}\left(R_{I L}\right) & {[8]} \\
p R^{\prime}{ }_{I L}=C_{p}^{\prime}\left(R_{L}\right) & {[9]} \\
\tau R_{L}^{\prime}=C_{p}^{\prime}\left(R_{L}\right) & {[10]} \\
p R^{\prime}{ }_{I L}=C_{s, l, p, j}^{\prime}\left(R_{L}\right) & {[11]}
\end{array}
$$

These allow us to extract the following theoretical results: i) from Equation 6, we see that the optimum well-being for a situation of partial legalization and where the economy is fully formalized occurs when the marginal increase of tax collection is the same as the marginal social costs arising from the use of other drugs; ii) from Equations 7 and 8, we know that, for partial legalization to have strength, for purposes of the informal economy for the drugs market, it is necessary that the probability of the criminal being arrested (p) grows, thereby increasing the marginal income resulting from confiscation - also, Equation 7 has a value which is higher than that of Equations 8 and 6; iii) the Nash equilibrium that provides the Government excedent in Equation 7 is Pareto superior if the reduction in the social costs resulting from legalization of drugs (changing from $\mathrm{C}_{\mathrm{s}, \mathrm{l}, \mathrm{p}, \mathrm{j}}$ to $\mathrm{C}_{\mathrm{s}}$ ) does not exceed the tax gains resulting from confiscations.

From the results above, we can say that the partial legalization of drugs, despite generating additional income by the collection of consumption tax, also leads to a rise in the Government's social costs. With this, there could be a reduction in the general well-being of society, depending on the relative strength of each member within this relationship. For the decriminalization of marijuana to bring some kind of real benefit, two conditions must be met: a) the probability of capture of the drug traffickers who still sell illicit drugs (p) must show significant growth and have a compensatory effect - however, this brings additional costs with law enforcement and depends on the degree of densification of the cities, as was foreseen by Brueckner (2011); b) There must also be an expansion in the volume of sale of illegal drugs, which is not desirable, unless there is a policy based on reinvestment of the sum confiscated, similar to that recorded by Atuesta and Hewings (2013).

Also, we see that, even though wider-scope legislation on use and commercialization of drugs provides an improvement in Government funding on the income side of things, there is only equilibrium and a more favourable outlook than the one at present if there is not a strong rise in social costs arising from this greater flexibility. In this regard, the specialised literature shows some papers that seek to see if the benefits of decriminalization of the use of marijuana would exceed the costs thereof.

Cheng, Mayer and Mayer (2018) found that this change in the Law is responsible for the increased value of some houses in some locations in Colorado, on reducing the occurrence of violent crime related to sale of illegal drugs, for example. Also, the study by Carrieri, Madio and Principe (2019) found a reduction in violent crime, thanks to an increase in the formal market, after legalization of drugs, in Italy in 2016. 


\section{CONCLUSIONS}

This article has investigated how the legalization of drugs, partially or completely, can affect the general well-being of society. For this reason, we have constructed a sequential game model with perfect information involving two people: the State (Government) and drug dealers. We have therefore established the incentive conditions that could make these criminals want to legalize or otherwise (working informally, through smuggling). Then, this paper analysed the possible Nash equilibriums that could arise and what payoffs they provide. In this regard, wellbeing is the utility provided by the expected value that the Government obtains on considering the tax income generated by the consumption and commercialization of drugs and the social costs thus incurred.

This study is different from others as previously released, as it uses Game Theory as a tool to extract logical and consistent information about the drug dealers' incentive structure. In this way, allowing the most effective mechanisms to be adopted so that the legalization of the use and commercialization of drugs is not just a way to create a legal façade for smuggling. Also, it assesses well-being for each possible situation.

As the main results, the study shows that: i) in a scenario where only marijuana is legalized, it is necessary that the probability of drug dealers insisting on the commercialization of other illicit drugs be arrested increase significantly, so that there is no more informality of the economy, which increases costs with law enforcement, through the need of greater policing, for example - in this regard, if the tax income does not compensate for this additional expense, there will be a Pareto worsening; ii) if the condition mentioned before is indeed met, then we see that the best Nash equilibrium, providing the best Government excedent and well-being, is the pair of strategies: Partial Legalization, Legal Sales + Smuggling. This fact backs up the idea that there is an optimum point within the fight against organized crime, to the extent that the taxes thus incurred may not be enough to balance out the expenses thus required.

As limitations of the study, issues that can be looked into at a later date, we have the assessment of the economic impact of partial legalization of drugs, from the standpoints of tax income and other expenses generated, leading to a system for measurement of well-being after politics. The greatest challenge of this calculation is the establishment of a proxy variable for income obtained by drug dealers ex-ante changes in the legislation, so that, next, one can estimate the differences in differences.

\section{REFERENCES}

ARRIA, A. M. et al.. (2013) Dispelling the myth of "smart drugs": Cannabis and alcohol use problemspredict nonmedical use of prescription stimulants for studying.Addictive behaviors, Elsevier,v. 38, n. 3, p. 1643-1650.

ATUESTA, L.; HEWINGS, G. J. (2013) "Economic welfare analysis of the legalization of drugs: a cge- 
microsimulation model for Colombia”. Economic Systems Research, Taylor \& Francis, v. 25,n. 2, p. 190-211.

BECKER, G. S.; MURPHY, K. M.; GROSSMAN, M. (2006) "The market for illegal goods: the case of drugs". Journal of Political Economy, JSTOR, v. 114, n. 1, p. 38-60.

BRUECKNER, J. K.(2019) Lectures on urban economics. [S.l.]: MIT Press, 2011.Bureau of Justice Statistics - BJS. 2019. Available at: <https://www.bjs.gov/index.cfm?ty=dca>. Acessed on: February 2019.

CARRIERI, V.; MADIO, L.; PRINCIPE, F. (2019) "Light cannabis and organized crime: Evidence from (unintended) liberalization in Italy". European Economic Review, v. 113 (c), Elsevier, 2019.

CHENG, C.; MAYER, W. J.; MAYER, Y.(2018) "The effect of legalizing retail marijuana on housing values: Evidence from Colorado”. Economic Inquiry, Wiley Online Library, v. 56, n. 3, p.15851601.

DEWEY, J. D. (1999) "Reviewing the relationship between school factors and substance use for elementary, middle, and high school students". Journal of Primary Prevention, Springer, v. 19,n. 3, p. $177-225$.

Federal Bureau of Prisons - BOP. (2019). Available at: <https://www.bop.gov/about/statistics/statistics_ inmate_offenses.jsp >. Acessed on: February 2019.

GALLET, C. A. (2014) "Can price get the monkey off our back? a meta-analysis of illicit drug demand". Health economics, Wiley Online Library, v. 23, n. 1, p. 55-68, 2014.

GIBBONS, R. (1997) "An introduction to applicable game theory". Journal of Economic Perspectives, v. 11, n. 1, p. 127-149.

JEYNES, W. H. (2002) "The relationship between the consumption of various drugs by adolescents and their academic achievement". The American Journal of Drug and Alcohol Abuse, Taylor \&Francis, v. 28, n. 1, p. 15-35.

MACCOUN, R.; REUTER, P. (1997) "Interpreting Dutch cannabis policy: reasoning by analogy in the legalization debate". American Association for the Advancement of Science, v. 278,n. 5335, p. 47-52.

MIRON, J. A. (2003) "The effect of drug prohibition on drug prices: Evidence from the markets for cocaine and heroin". Review of Economics and Statistics, MIT Press, v. 85, n. 3, p. 522-530.

National Center for Health Statistics - NCHS. (2017) Drug overdose deaths in the united states, 1999 2016. nchs data brief. number 294. National Center for Health Statistics.

National Institute on Drug Abuse - NIDA. (2019). Available at:<https://www.drugabuse.gov/relatedtopics/trends-statistics\#supplemental-references-for-economic-costs>. Acessed on: February 2019.

National Prisoner Statistics - NPS. 2019. Available at: <https://www.census.gov/econ/overview/go3000. html>. Acessed on: February 2019.

NEUMANN, J. V.; MORGENSTERN, O. (2007) Theory of games and economic behavior (commemorative edition). [S.1.]: Princeton university press.

NISBET, C. T.; VAKIL, F. (1972) "Some estimates of price and expenditure elasticities of demand for marijuana among UCLA students'. The Review of Economics and Statistics, JSTOR, p. 473475,1972 .

OURS, J. C. V. (1995) "The price elasticity of hard drugs: The case of opium in the dutch east indies,1923-1938". Journal of Political Economy, The University of Chicago Press, v. 103, n. 2, p.261-279.

OURS, J. C. V. (2007) "The effects of cannabis use on wages of prime-age males". Oxford Bulletin of Economics and Statistics, Wiley Online Library, v. 69, n. 5, p. 619-634, 2007.

POPOVICI, I.; FRENCH, M. T. (2014) "Cannabis use, employment, and income: fixed-effects analysis of panel data". The Journal of Behavioral Health Services \& Research, Springer, v. 41, n. 2, p.185-202.

RASHAD, I.; KAESTNER, R. (2004) "Teenage sex, drugs and alcohol use: problems identifying the cause of risky behaviors". Journal of Health Economics, Elsevier, v. 23, n. 3, p. 493-503.

SAFFER, H.; CHALOUPKA, F. (1999) "The demand for illicit drugs". Economic Inquiry, Wiley OnlineLibrary, v. 37, n. 3, p. 401-411.

SUTHERLAND, I.; SHEPHERD, J. P. (2018) "Social dimensions of adolescent substance use". Addiction, Wiley Online Library, v. 96, n. 3, p. 445-458, 2001. 
Tax and Budget Bulletin. Tax and budget bulletin.Cato Institute, July, 2018.United States Sentence Comission - USSC. 2019. Available at: <https://www.ussc.gov/research/datafiles/commissiondatafiles>. Acessed on: February 2019.

WORLD DRUG REPORT, (2017), United Nations Publications.

YAMAGUCHI, K.; KANDEL, D. (1987) "Drug use and other determinants of premarital pregnancy and its outcome: A dynamic analysis of competing life events". Journal of Marriage and the Family, JSTOR, p. 257-270.

ZARKIN, G. A. et al.. (1998) "The relationship between drug use and labor supply for young men". Labour Economics, Elsevier, v. 5, n. 4, p. 385-409.

\section{APPENDIX A - DESCRIPTIVE STATISTICS: SENTENCED CRIMINALS - 2017}

Table 4: Descriptive Statistics: Sentenced Criminals - 2017

\begin{tabular}{|c|c|c|}
\hline Characteristics & Drug Dealers & Source \\
\hline Male & $83.8 \%$ & Bureau of Justice Statistics - BJS (2019) \\
\hline Female & $16.2 \%$ & Bureau of Justice Statistics - BJS (2019) \\
\hline Mean Age & 29.38 years & Bureau of Justice Statistics - BJS (2019) \\
\hline \multicolumn{3}{|l|}{ Citizenship } \\
\hline American & $74.1 \%$ & Bureau of Justice Statistics - BJS (2019) \\
\hline Foreign & $25.95 \%$ & Bureau of Justice Statistics - BJS (2019) \\
\hline \multicolumn{3}{|l|}{ Ethnicity } \\
\hline White & $22.4 \%$ & Bureau of Justice Statistics - BJS (2019) \\
\hline Black & $24.6 \%$ & Bureau of Justice Statistics - BJS (2019) \\
\hline Hispanic & $49.8 \%$ & Bureau of Justice Statistics - BJS (2019) \\
\hline Other & $3.2 \%$ & Bureau of Justice Statistics - BJS (2019) \\
\hline \multicolumn{3}{|l|}{ Schooling } \\
\hline Less than High School & $36.6 \%$ & National Prisoner Statistics - NPS (2019) \\
\hline High School & $52.0 \%$ & National Prisoner Statistics - NPS (2019) \\
\hline University Studies & $11.4 \%$ & National Prisoner Statistics - NPS (2019) \\
\hline $\begin{array}{l}\text { Mean time of imprisonment: } \\
\text { drug trafficking }\end{array}$ & 73.53 months & $\begin{array}{l}\text { Calculated based on data from the United } \\
\text { States Sentence Commission - USSC (2019) }\end{array}$ \\
\hline $\begin{array}{l}\text { Mean time of imprisonment: } \\
\text { smuggling }\end{array}$ & 17 months & $\begin{array}{l}\text { Calculated based on data from the United } \\
\text { States Sentence Commission - USSC (2019) }\end{array}$ \\
\hline $\begin{array}{l}\% \text { of total inmates impriso- } \\
\text { ned for drug-related crimes }\end{array}$ & $45.9 \%$ & Federal Bureau of Prisons - BOP (2019) \\
\hline
\end{tabular}

Source: Prepared by the authors. 